\title{
Terapi Sulih Testosteron Meningkatkan Ekspresi Messenger Ribonucleaic Acid (mRNA) RESEPTOR Androgen pada Penis Tikus Wistar (Rattus norvegicus) Dewasa yang Dikastrasi
}

\author{
Ni Putu Rahayu Dwi Asti Indira \\ Program Magister Ilmu Biomedik Universitas Udayana \\ ayu.indira2085@yahoo.com
}

\begin{abstract}
Diterima: 20 Juni 2016. Disetujui: 28 Juni 2016. Diterbitkan: Agustus 2016
ABSTRAK

Hormon testosteron pada pria mengalami penurunan seiring terjadinya proses penuaan sehingga mengakibatkan ekspresi mRNA reseptor androgen pada jaringan penis juga menurun. Penurunan ekspresi mRNA androgen reseptor pada penis mengakibatkan atrofi pada jaringan erektil penis sehingga menimbulkan keluhan pada fungsi organ reproduksi dan seksual pria. Hormon testosteron berperan memodulasi proliferasi jaringan erektil penis melalui regulasi reseptor androgen, namun efek pemberian terapi sulih testosteron terhadap ekspresi mRNA AR pada penis masih terbatas. Rancangan penelitian ini menggunakan Randomized Post-Test Only Control Group Design. Penelitian dilakukan di Laboratorium Histologi Universitas Udayana selama 12 minggu terhadap 36 ekor tikus wistar dewasa kastrasi yang dibagi menjadi 2 kelompok, yaitu 1 kelompok kontrol dan 1 kelompok perlakuan. Kelompok kontrol diberikan suntikan Aquabidest $18 \mu \mathrm{l} /$ minggu secara intramuskular dan kelompok perlakuan diberikan suntikan testosteron $4,5 \mathrm{mg} / 250 \mathrm{gr} \mathrm{BB} /$ minggu secara intramuskular. Setelah 28 hari seluruh tikus dieutanasia dan diambil jaringan penisnya untuk pemeriksaan ekspresi mRNA AR. Ekspresi mRNA AR diukur dengan menggunakan metode real time PCR. Analisis komparasi dengan $t$-independence test pada data ekspresi mRNA AR posttest menunjukkan hasil yang berbeda bermakna dengan nilai $p=0,001(p<0,05)$. Simpulan penelitian ini ialah terapi sulih testosteron (testosterone replacement therapy) meningkatkan ekspresi messenger ribonucleaic acid (mRNA) reseptor androgen pada penis tikus wistar (Rattus norvegicus) dewasa yang dikastrasi.
\end{abstract}

Kata kunci: Terapi Sulih Testosteron, Reseptor Androgen, Ekspresi mRNA.

\section{ABSTRACT}

The hormone testosterone in male decrease by the aging process, resulting decreased in mRNA expression of androgen receptors in penile tissue. The decline of androgen receptor mRNA expression penis, resulting atrophy in the erectile tissue and causing complaints on sexual function and male reproductive organs. The hormone testosterone modulates the proliferation of erectile tissue through regulation of androgen receptors, but there is little known about the effect of testosterone replacement therapy on the mRNA expression of Androgen Receptor in penile. The purpose of this study was to prove administration of testosterone replacement therapy can increase the mRNA expression of AR in castrated adult rat penile. The research design used Randomized Post Test Only Control Group Design. The study was conducted at the Laboratory Histology of Udayana University for 12 weeks in 36 adult rat castrated which were divided into 2 groups; control group and treatment group. The control group was given an injection of aquabidest $18 \mu \mathrm{l} /$ week intramuscular and the treatment group was given testosterone injections 4,5mg/250grBB/week intramuscular. After 28 days all rat were euthanized, their penile was taken for examination mRNA expression of AR. mRNA expression of AR measured by using real time PCR method. Data were analysed with $t-$ independence test. mRNA expression of AR for both group were statistically significant with $p$ value $=$ $0,001(p<0,05)$. The conclusion of this study was that testosterone replacement therapy increased expression mRNA androgen receptor in castrated adult rat penile.

Keywords: Testosterone Replacement Therapy, Androgen Receptor, mRNA Expression 
maupun pria. Semakin bertambahnya usia, berbanding terbalik dengan kadar hormon seseorang. Aging proses pada pria menyebabkan penurunan tiga sistem hormonal, yaitu hormon testosteron, dehydroephyandrosteron (DHEA/DHEAS), serta insulin growth factor (IGF) dan growth hormone (GH). Pada pria dengan andropause, penurunan fungsi sistem reproduksi mengakibatkan penurunan jumlah testosteron dan availabilitasnya seiring dengan meningkatnya SHBG. ${ }^{1}$

Penuaan pada pria meskipun merupakan keadaan yang fisiologis, namun berbagai masalah juga dapat timbul seiring terjadinya aging proses. Penurunan androgen menimbulkan masalah yang mendasar bagi kesehatan reproduksi pria, mengingat peranan androgen dalam pengembangan dan pemeliharaan fungsi organ reproduksi dan seksual laki-laki sangat besar yang nantinya apabila terganggu dapat mempengaruhi kualitas hidup. Testosteron yang rendah dihubungkan dengan penurunan libido, disfungsi ereksi, peningkatan masa lemak, penurunan masa otot dan tulang, serta penurunan energi, depresi, dan anemia. ${ }^{2}$

Defisiensi androgen pada pria menyebabkan terganggunya perkembangan dan pemeliharaan jaringan organ seks pada pria. Penelitian mengenai peran androgen terhadap pemeliharaan ultrastruktur jaringan penis yang dilakukan pada binatang menunjukkan bahwa kekurangan hormon testoteron menyebabkan atropi jaringan erektil penis, perubahan struktur nervus dorsalis, perubahan morfologi endotel, penurunan otot polos trabekular, dan akumulasi jaringan lemak pada daerah subtunika korpus kavernosum. $^{3}$

Level androgen yang menurun pada saat terjadinya aging proses menyebabkan penurunan reseptor androgen, begitu pula level AR pada tikus yang dikastrasi. Penurunan reseptor androgen mempengaruhi ekspresi mRNA reseptor androgen pada jaringan erektil khusunya penis, sehingga proliferasi sel pada jaringan terganggu dan berakibat pada atrofi jaringan erektil penis. Peran androgen dalam menjaga ultrastruktur organ reproduksi tidak terlepas dari mekanisme reseptor androgen (AR). Reseptor androgen merupakan anggota dari reseptor nuclear. Peran reseptor androgen sangat penting sebab reseptor androgen memediasi aksi androgen untuk menjalankan perannya dalam perkembangan dan fungsi organ reproduksi pada pria seperti halnya jaringan erektil pada penis dan ultrastruktur jaringan vagina pada wanita. ${ }^{4}$ Mekanisme dari proliferasi pada jaringan target androgen dimediasi melalui androgen signaling pathway yaitu secara genomic dan nongenomik. ${ }^{5}$

Penelitian mengenai peran testosteron terhadap ekspresi mRNA reseptor androgen pada penis tikus masih terbatas dan masih menjadi perdebatan secara mekanisme serta regulasinya. Penelitian terbaru yang dilakukan oleh Yan et al., (2014) mebuktikan bahwa hormon testosteron meregulasi ekspresi keratin 33B yang berperan pada pertumbuhan penis tikus melalui mekanisme signal reseptor androgen. Penelitian mengenai pemberian preparat testosteron pada hewan percobaan khususnya tikus selama ini memberikan hasil yang bermakna terhadap perkembangan jaringan erektil penis.

Berdasarkan hal tersebut peneliti ingin membuktikan terapi sulih testosteron dengan dosis $4,5 \mathrm{mg} / 250$ grBB berdasarkan dosis konversi manusia ke tikus mampu meningkatkan ekspresi mRNA AR pada penis tikus wistar yang dikastrasi.

\section{BAHAN DAN METODE \\ Protokol Perlakuan Hewan Coba}

Penelitian ini menggunakan 36 ekor tikus wistar (Rattus norvegicus) jantan dewasa, usia 2022 minggu dengan berat badan 200-250 gram. Tikus diperoleh dari Balai Besar Veterenier Denpasar. Penelitian dilakukan di Laboratorium Histologi Universitas Udayana. Tikus diberikan pakan secara ad libitum dan diadaptasi selama satu minggu sebelum dilakukan kastrasi. Kastrasi dilakukan setelah tikus diberikan anastesi. Empat minggu setelah kastrasi, tikus dibagi menjadi dua kelompok secara acak yaitu kelompok kontrol dan perlakuan. Kelompok kontrol diberikan injeksi aquabidest $18 \mu \mathrm{l} / \mathrm{minggu}$, kelompok kontrol diberikan injeksi testosteron 4,5mg/250 grBB setiap minggu secara intramuskular dengan spuit Hamilton. Perlakuan berlangsung selama 28 hari, hari ke 29 tikus diterminasi dengan ketamin. Bagian penis tikus diambil dengan cara dilakukan pemotongan hingga radix penis.

\section{Persiapan Sampel}

Sampel jaringan penis (bagian korpus) dipotong dengan ketebalan $5 \mathrm{~mm}$ seberat $20 \mathrm{mg}$ kemudian direndam dalam larutan RNAlater menggunakan tabung eppendorf dengan perbandingan 1:20 selama 24 jam dalam suhu $4^{\circ} \mathrm{C}$. Sampel diambil dari larutan kemudian dimasukkan ke dalam tabung eppendorf baru dan disimpan pada suhu $-20^{\circ} \mathrm{C}$.

\section{Ekstraksi RNA}

Sampel diambil dan ditimbang (maksimal 15-20 mg). Sampel kemudian dihancurkan dan homogenisasi dan jaringan dimasukkan ke dalam 
selama 1 menit pada 8000 x g. Simpan pada $-20^{\circ} \mathrm{C}$ sebelum dilanjutkan pada langkah berikutnya.

\section{Metode Kuantitatif Relatif 1-step qRT-PCR}

PCR dilakukan dalam total volume $20 \mu \mathrm{l}$, dengan komposisi seperti pada Tabel 1.

Tabel 1. Komposisi Volume PCR

\begin{tabular}{ll}
\hline \multicolumn{1}{c}{ Reagent } & $1 \mathrm{X}$ \\
\hline Kapa SYBR Fast (2 X) & $10 \mathrm{ul}$ \\
F primer (10 uM) & $0.4 \mathrm{ul}$ \\
R primer (10 uM) & $0.4 \mathrm{ul}$ \\
Kapa RT mix (50x) & $0,4 \mathrm{ul}$ \\
Sampel mRNA & $2 \mathrm{ul}$ \\
RNAase free water & $6.8 \mathrm{ul}$ \\
\multicolumn{1}{c}{ TOTAL } & $20 \mathrm{ul}$ \\
\hline
\end{tabular}

Primer yang digunakan untuk mRNA AR dan GAPDH ditunjukan pada Tabel $2 .^{6} 1$-step qRT-PCR dilakukan pada RotorGene Qiagen dengan setting seperti pada Tabel 3.

Tabel 2. Primer mRNA dan GAPDH

\begin{tabular}{lc}
\hline \multicolumn{1}{c}{ Target } & \multicolumn{1}{c}{ Sequence 5'-3' } \\
\hline Forward Gen Androgen Receptor & GGAGAACTCTTCAGAGCAAC \\
Reverse Gen Androgen Receptor & AGCTGAGTCATCCTGATCTG \\
Forward Gen ACTB & TCGTGCGTGACATTAAAGAG \\
Reverse Gen ACTB & ATTGCCGATAGTGATGACCT \\
\hline
\end{tabular}

Tabel 3. Setting dalam 1-step qRT-PCR

\begin{tabular}{cccccc}
\hline No & Proses & Suhu & Waktu & Siklus & Tambahan \\
\hline 1 & RT & 42 & 5 menit & 1 & - \\
2 & Aktivasienzim & $95^{\circ} \mathrm{C}$ & 5 menit & 1 & - \\
3 & Denaturasi & $95^{\circ} \mathrm{C}$ & 3 detik & 40 & - \\
4 & Annealing & $59^{\circ} \mathrm{C}$ & 20 detik & 40 & Green channel diaktifkan \\
\hline
\end{tabular}

\section{Analisis Data}

Data yang diperoleh dari hasil penelitian disajikan dalam bentuk grafik rata-rata ekspresi mRNA ER $\alpha$ dan AR pada kelompok kontrol dan perlakuan. Perbedaan rata-rata ekspresi mRNA ER $\alpha$ dan AR pada kelompok kontrol dan perlakuan diuji dengan menggunakan independent t-test dengan software SPSS 16.0 dengan $\mathrm{p}=0,05$.

HASIL

\section{Ekspresi mRNA AR}

Berdasarkan hasil analisis dengan menggunakan metode Real Time-PCR didapatkan hasil seperti disajikan dalam tabel 4 .

Tabel 4. Ekspresi mRNA AR pada Kelompok Kontrol dan Kelompok Perlakuan.

\begin{tabular}{lccc}
\hline Ekspresi mRNA AR & $\mathrm{n}$ & Rerata $(\mathrm{pg} / \mu \mathrm{l})$ & $\mathrm{SD}$ \\
\hline kontrol & 18 & 4,20 & 0,92 \\
perlakuan & 18 & 12,91 & 1,37 \\
\hline
\end{tabular}

Tabel 4 menunjukkan rerata ekspresi mRNA AR kelompok kontrol sebesar 4,20 $\pm 0,92 \mathrm{pg} / \mu \mathrm{l}$ dimana lebih tinggi dibandingkan kelompok perlakuan sebesar $12,91 \pm 1,37 \mathrm{pg} / \mu \mathrm{l}$.

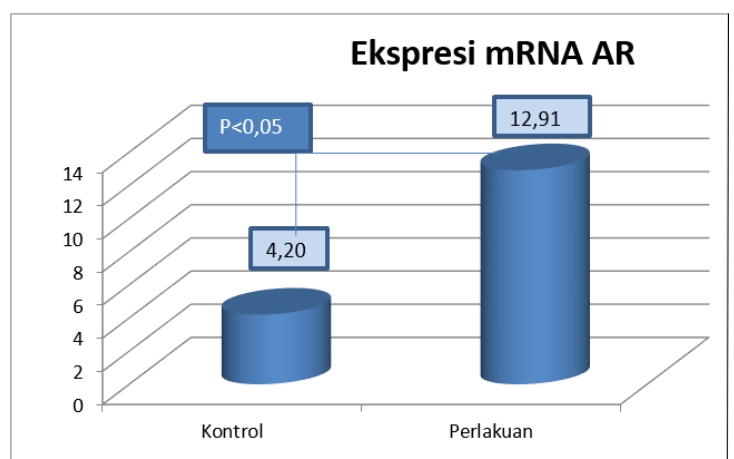

Gambar 1.

Perbedaan Ekspresi mRNA Reseptor Androgen pada Kelompok Kontrol dan Kelompok Perlakuan. 
Aktivasi reseptor androgen protein terjadi

Efek pemberia terapi sulih testosteron terhadap ekspresi mRNA AR dapat diketahui dengan melakukan pengujian terhadap perbedaan rerata ekspresi mRNA AR pada kelompok kontrol dan perlakuan dengan independent t-test. Hasil uji T menunjukkan nilai $p=0,001(p<0,05)$ yang artinya perbedaan rerata ekspresi mRNA AR kelompok kontrol dan perlakuan signifikan secara statistik.

\section{DISKUSI}

Produksi testosteron pada pria dikendalikan oleh hipotalamus - hipofisis - gonad (HPG) axis. Gonadotropin-releasing hormone (GnRH) disekresikan dari hipotalamus, sehingga merangsang kelenjar hipofisis untuk melepaskan hormon luteinizing (LH), yang bekerja pada sel-sel testis Leydig untuk memproduksi testosteron. Produksi hormon dipengaruhi oleh penuaan. Sejumlah hormon mengalami penurunan akibat dari proses penuaan, seperti halnya hormon androgenik (dehydroepiandrosterone dan sulfatnya) yang dilepaskan dari kelenjar adrenal. Pengurangan kadar testosteron bebas terjadi sebesar $1 \%$ per tahun antara usia 40 tahun dan 70 tahun. Penurunan ini disebabkan oleh konsentrasi SHBG meningkat pada tingkat 1,2 \% pertahun. Fraksi testosteron bebas menurun secara proporsional seiring dengan peningkatan jumlah situs testosteron mengikat SHBG. Penuaan berimbas pula pada fungsi sel Leydig dan menunkan sensitivitas HPG axis. ${ }^{1}$

Hormon testosteron selama ini diketahui memegang peranan dalam pemeliharaan jaringan erektil pada penis. Dua puluh delapan hari pasca kasterasi menyebabkan jaringan korpus kavernosum, endothelia vaskular, tunika albuginea pada penis mengalami atrofi. ${ }^{7}$ Hormon testosteron memodulasi perkembangan dan pemeliharaan ultrastruktur jaringan erektil penis dengan mekanisme reseptor androgen. Peningkatan level androgen akan meningkatkan ekspresi mRNA reseptor androgen pada jaringan sehingga proliferasi sel akan terjadi, hal ini sesuai dengan hasil penelitian, rata-rata ekspresi mRNA AR pada kelompok kontrol adalah 4,20 $\pm 0,92 \mathrm{pg} / \mu \mathrm{l}$ sedangkan pada kelompok perlakuan sebesar $12,91 \pm 1,37 \mathrm{pg} / \mu \mathrm{l}$. Perbedaan ini signifikan secara statistik setelah diuji menggunakan uji $\mathrm{T}$ tidak berpasangan dengan nilai $p=0,001(p<0,05)$.

Androgen memiliki struktur hidrofobik steroid kolesterol, yang memungkinkan untuk bergerak bebas dari luar sel menuju ke dalam sel. Target intraselular androgen adalah AR. Setelah berikatan dengan androgen, AR bergerak menuju nukleus dan mengatur transkripsi pada target gen androgen. ${ }^{8}$ setelah pemberian testosteron terapi, androgen akan memodulasi ekspresi mRNA AR melalui regulasi posttranskripsi. Ekspresi dari mRNA reseptor androgen pada penis tikus dikaitkan dengan ikatan nuclear protein penis pada reseptor androgen gene promoter yang berkorelasi dengan reseptor ekspresi gen. Mekanisme dari ekspresi mRNA AR berlangsung secara genomik dan nongenomik. Mekanisme utama dari reseptor androgen adalah pengaturan langsung dari transkripsi gen. Pengikatan androgen pada reseptor androgen menghasilkan perubahan konformasi dalam reseptor, pada akhirnya menyebabkan disosiasi heat shock protein, transportasi dari sitosol ke dalam inti sel, dan dimerisasi. Dimer reseptor androgen mengikat urutan tertentu dari DNA yang dikenal sebagai elemen respon hormon. Reseptor androgen berinteraksi dengan protein lain dalam nucleus sehingga menghasilkan up atau down regulasi dari spesifik transkripsi gen. Up-regulasi atau aktivasi dari transkripsi menghasilkan peningkatan sintesis messenger RNA, yang nantinya diterjemahkan oleh ribosom untuk memproduksi protein spesifik tertentu. $^{9}$

Nongenomic action dari androgen dapat terjadi melalui beberapa reseptor. Androgen dapat mengaktifkan Camp dan PKA melalui SHBG (Sex Hormone Binding Globulin) / SHBG kompleks. Nongenomic distimulasi secara cepat melalui second messenger cascades oleh androgen pada akhirnya dapat memberi efek biologis melalui modulasi aktivitas faktor transkripsi AR. Modulasi tersebut dapat terjadi melalui fosforilasi langsung aktivator transkripsi atau koregulator. AR juga dapat diaktifkan tanpa adanya ligan yang sama. ${ }^{10}$

\section{SIMPULAN}

Berdasarkan hasil penelitian dapat disimpulkan bahwa terapi sulih testosteron meningkatkan ekspresi messenger ribonucleaic acid (mRNA) reseptor androgen pada penis tikus wistar (Rattus norvegicus) dewasa yang dikastrasi.

\section{DAFTAR PUSTAKA}

1. Rolf C, Zitzmann, Michael, Nieschlag E. The Aging Male and Late-Onset Hypogonadism. Muaster: Springer; 2010.

2. Dandona P, Dhindsa S, Chandel A, Topiwala S. Low Testosterone in Men with Type-2 Diabetes-a Growing Public Health Concern. J Diabetes Voice. 2009; 54: 27-29.

3. Sakka Al, Yassin AA. Amelioration of Penile Fibrosis: Myth or Reality. Journal of Andrology. 2010; 31: 324-334. 
4. Xinchang Z. 2010. Roles of Androgen Receptor in Male and Female Reproduction Lesson from Global and Cell Specific Androgen Receptor Knock Out (ARKO) Mice. Journal of Andrology. 2010; 31:3.

5. Yan MM, Wa K, Qiang D, Qi S, Yang G. Testosterone regulates keratin 33B expression in rat penis growth through androgen receptor signaling. Asian J Androl. 2014; NovDec;16(6):817-23. doi: 10.4103/1008-682X. 129935.

6. Funahashi $\mathrm{Y}, \mathrm{O}^{\prime}$ Malley KJ, Kawamorita N, Tyagi $P$, DeFranco DB, Takahashi R, Gotoh M, Wang $Z$, Yoshimura N. Upregulation of androgenresponsive genes and transforming growth factor-beta1 cascade genes in a rat model of non-bacterial prostatic inflammation. The Prostate. 2014; 74, pp :337-345.

7. Natoli AK, Medley TL, Ahimastos AA, Drew BG, Thearle DJ, Dilley RJ, Kingwell BA. Sex steroids modulate human aortic smooth muscle cell matrix protein deposition and matrix metalloproteinase expression. Hypertension. 2005; 46:1129-1134.

8. Lambert. Molekular Mechanism of Androgen Receptor Function. Nederland: Wohrmann, Zutpen; 2007.

9. Culig Z, Klocker H, Bartsch G, Steiner H, Hobisch A. Androgen Receptors in Prostate Cancer. J Urol. 2003; Oct;170(4):1363-1369.

10. Heinlein CA, Chang $C$. The roles of androgen receptors and androgen-binding proteins in nongenomic androgen actions. Mol Endocrinol. 2002; Oct;16(10):2181-7.

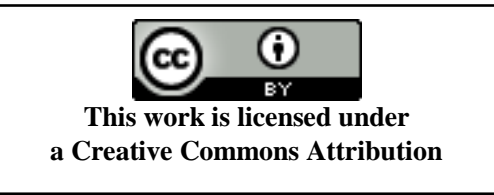

